\title{
Molecular characterization of yeasts isolated from traditional Turkish cheeses
}

\author{
Sine OZMEN TOGAY ${ }^{1 \star ~(D), ~ A n g e l a ~ C A P E C E ², ~ G a b r i e l l a ~ S I E S T O ~}{ }^{2}$, Harun AKSU ${ }^{3}$, \\ Sema SANDIKCI ALTUNATMAZ ${ }^{4}$, Filiz YILMAZ AKSU4, Patrizia ROMANO², Yonca KARAGUL YUCEER ${ }^{5}$
}

\begin{abstract}
Thirty-two yeast strains were identified by means of molecular methods isolated from traditional Turkish cheeses (Tulum, Kashkaval, Mihalic, Orgu, White, Sepet, and Goat). Debaryomyces hansenii and Torulaspora delbrueckii were found as predominant species in cheese samples. Other species which were identified were Kluyveromyces lactis, Candida parapsilosis, Clavispora lusitaniae, Saccharomyces cerevisiae, Kluyveromyces marxianus, Rhodotorula mucilaginosa, Meyerozyma guilliermondii (formerly Pichia guilliermondii), Candida zeylanoides and Candida albicans. Rhodotorula mucilaginosa and D. hansenii strains, from Kashkaval cheese, showed antilisterial activity, whereas only one K. lactis strain from Orgu cheese exhibited proteolytic activity.

Keywords: Tulum, Kashkaval, Mihalic, Orgu, White, Sepet, and Goat cheeses; Debaryomyces hansenii; Torulaspora delbrueckii; Kluyveromyces lactis; Rhodotorula mucilaginosa; characterization; antimicrobial activity.

Practical Application: The wild yeast microflora from some traditional Turkish cheeses were identified by means of molecular techniques. These information may be useful for quality and shelf life of Turkish cheeses.
\end{abstract}

\section{Introduction}

Yeasts are an essential part of cheese microflora because they can tolerate low water activity and $\mathrm{pH}$, high salt concentrations and low storage temperatures and are resistant to some chemicals such as sanitizers and cleaning compounds (Ferreira \& Viljoen, 2003; Banjara et al., 2015). Certain yeasts may have the ability to use lactose, proteins, lipids, and some organic acids and may be applied for ripening by generating some flavor components and modifying the texture of cheeses and dairy products. Traditional fermented dairy products such as kefir and kumys are also produced by lactic acid bacteria and yeast fermentation (Jakobsen \& Narvhus, 1996; Vasdinyei \& Deak, 2003; Ferreira \& Viljoen, 2003; Büchl \& Seiler, 2011; Banjara et al., 2015).

At the same time, some yeast strains can cause spoilage by producing gas, off-flavors, softening of texture and discoloration changes in dairy products, especially with low $\mathrm{pH}$ such as yogurt, cream cheese, fermented milk, sour cream, etc. (Vasdinyei \& Deak, 2003; Kavas et al., 2006; Büchl \& Seiler, 2011; Corbaci et al., 2012).

Yeasts may enter cheese production process from a variety of sources, such as the starter microorganisms, brine, environmental air, workers, and processing equipment (Banjara et al., 2015). The most commonly isolated yeast genera from dairy products are Debaryomyces, Yarrowia, Candida, Zygosaccharomyces, Cryptococcus, Geotrichum, Kluyveromyces, Trichosporon, Rhodotorula, Torulaspora, and Saccharomyces. Kluyveromyces marxianus, Debaryomyces hansenii, and Saccharomyces cerevisiae species are mostly presented in dairy samples. Besides, Yarrowia lipolytica and $D$. hansenii may also be used as adjunct cultures for flavor enhancement during cheese ripening (Hansen \& Jakobsen, 2001; Ferreira \& Viljoen, 2003; Vasdinyei \& Deak, 2003; Capece \& Romano, 2009).

Turkish White cheese, Kashkaval, and Tulum cheeses are the best known and the most commonly consumed cheese varieties which have a national and economic value in Turkey. Mihalic, Orgu, Sepet, and Goat cheese are the other crucial Turkish cheese varieties (Hayaloglu et al., 2002; Kamber, 2008; Aday \& Karagul Yuceer, 2014).

In the researches about yeast microflora of Turkish cheeses, $D$. hansenii, Pichia amethionina var. amethionina, $K$. lactis and Candida spp., were identified in Turkish White cheeses (Hayaloglu et al., 2002); Candida, Geotrichum, Kluyveromyces, Pichia, Saccharomyces and Zygosaccharomyces genera were found in Tulum cheeses (Karasu-Yalcin et al., 2012); Debaryomyces spp., Candida spp, Kluyveromyces spp., Trichosporon spp., Saccharomyces spp. and Geotricum spp. were obtained from Tulum, white pickled and, Kasar (Kashkaval) cheeses (Kavas et al., 2006); Candida (especially C. famata var. famata), Geotrichum and Trichosporon spp. were identified as dominant yeast flora in Mihalic cheeses (Karasu-Yalcin et al., 2017); and D. hansenii was found as predominant yeast species in homemade cheeses (Corbaci et al., 2012).

It has also been mentioned that certain species of yeasts may have inhibition characteristics against spoilage or pathogenic microorganisms in cheeses. D. hansenii may have

${ }^{1}$ Department of Food Engineering, Faculty of Agriculture, Bursa Uludag University, Bursa, Turkey

${ }^{2}$ Scuola di Scienze Agrarie, Forestali, Alimentari ed Ambientali, University of Basilicata, Via dell'Ateneo Lucano, Potenza, Italy

${ }^{3}$ Department of Food Hygiene and Technology, Veterinary Faculty, Istanbul University-Cerrahpasa, Avcilar, Istanbul, Turkey

${ }^{4}$ Department of Food Technology, Veterinary Vocational School, Istanbul University-Cerrahpasa, Avcilar, Istanbul, Turkey

${ }^{5}$ Department of Food Engineering, Engineering Faculty, Çanakkale Onsekiz Mart University, Çanakkale, Turkey

*Corresponding author: sineozmen@gmail.com; sinetogay@uludag.edu.tr 
antibacterial activity against Clostridium butyricum and $C$. tyrobutyricum in cheese brines (Ferreira \& Viljoen, 2003). The antimicrobial activity of yeasts has been known for years. It is thought that antagonistic effects of yeasts are obtained through competition for nutrients, production of ethanol and organic acid, antimicrobial compounds such as extracellular proteins or glycoproteins called mycocins (Hatoum et al., 2013; Buyuksirit \& Kuleasan, 2014). Certain yeast genera, such as Saccharomyces, Debaryomyces, Cryptococcus, Candida, Hanseniaspora, Kluyveromyces, Pichia, Torulopsis, Williopsis and Zygosaccharomyces, may produce mycocins (Hatoum et al., 2012; Buyuksirit \& Kuleasan, 2014).

In this research, the wild yeast strains isolated from traditional Turkish cheeses were identified by means of molecular techniques. The antagonistic effect and the proteolytic and lipolytic activities of the isolates were also evaluated.

\section{Materials and methods}

\subsection{Yeast isolation}

The cheese samples belonging to Tulum, Kashkaval, Mihalic, Orgu, White, Sepet, and Goat cheese varieties were collected $(\mathrm{n}=50)$. Samples $(25 \mathrm{~g})$ were weighed in sterile bags and homogenized in $225 \mathrm{~mL}$ buffered peptone water using a peristaltic blender (Stomacher, ISOLAB, Turkey). The decimal dilutions of the samples were spread on YEPD (yeast extract-peptone-dextrose) agar (Merck, Darmstadt, Germany) medium with $0.1 \mathrm{~g} / \mathrm{L}$ chloramphenicol (Merck, Darmstadt, Germany) added and incubated during 2-6 days at $28^{\circ} \mathrm{C}$. One to three colonies were selected randomly from the YEPD agar, subcultured to obtain pure cultures on YEPD medium (Capece \& Romano, 2009).

\subsection{Yeast identification}

Genomic DNA extraction was performed using a synthetic resin (Instagene Bio-Rad Matrix), following the protocol described by Capece et al. (2011). The presumptive identification of the yeasts obtained from traditional Turkish cheeses was performed by PCR amplification of the internal transcribed spacers between the $18 \mathrm{~S}$ and $26 \mathrm{~S}$ rDNA genes (ITS1-5.8S-ITS2) and subsequent restriction analysis, as reported by Esteve-Zarzoso et al. (1999). PCR products were digested without further purification with restriction enzymes HaeIII and HinfI (Promega, USA). Restricted fragments were analyzed by electrophoresis on $2 \%$ agarose gels, and 1.0X TBE buffer, stained with SyberSafe DNA gel stain (Invitrogen, USA) and the obtained profiles were visualized and photographed with Gel Doc ${ }^{\mathrm{TM}} \mathrm{XR}+$ (Bio-Rad, USA) under UV light. A 100-bp DNA ladder marker (Promega, USA) served as the standard size. Isolates showing the same restriction pattern were grouped, and one or two representative yeasts for each group were delivered to Eurofins Genomics Srl (Vimodrone, Italy) for sequencing. The sequences received were compared with those deposited in the GenBank DNA database (National Center for Biotechnology Information, 2015) using the basic BLAST search tools (Altschul et al., 1997).

\subsection{Molecular characterization using MSP-PCR}

The genetic variability among the analyzed strains was evaluated by means of microsatellite-primed PCR (MSP-PCR) experiments. The primers employed in MSP-PCR assays were the minisatellite M13 (GAGGGTGGCGGTTCT) and the microsatellite synthetic oligonucleotide (GTG) . Amplification reactions were done in a total volume of $50 \mu \mathrm{L}$ containing $10 \mu \mathrm{L}$ of Taq Polymerase 5X Buffer (Promega, USA), $4.0 \mu \mathrm{L}$ of $25 \mathrm{mM}$ $\mathrm{MgCl}_{2}$ (Promega, USA), $1 \mu \mathrm{L}$ of $10 \mathrm{mM}$ dNTP (Promega, USA), $5 \mu \mathrm{L}$ of $5 \mu \mathrm{M}$ primer, $0.25 \mu \mathrm{L}(5 \mathrm{U} / \mu \mathrm{L})$ of Taq DNA polymerase (Promega, USA) and $5 \mu \mathrm{L}$ of the extracted DNA, by adding sterile water until final volume. The thermal cycler was programmed as follows: initial denaturation at $95^{\circ} \mathrm{C}$ for $5 \mathrm{~min}$, followed by 35 cycles at $94^{\circ} \mathrm{C}$ for $1 \mathrm{~min}, 1 \mathrm{~min}$ at $52^{\circ} \mathrm{C}, 2 \mathrm{~min}$ at $72^{\circ} \mathrm{C}$ for (GTG) ${ }_{5}$, while the initial denaturation was followed by 40 cycles at $95{ }^{\circ} \mathrm{C}$ for $40 \mathrm{sec}, 1 \mathrm{~min}$ at $52{ }^{\circ} \mathrm{C}, 1 \mathrm{~min}$ at $72{ }^{\circ} \mathrm{C}$; the final extension step for both primers was at $72^{\circ} \mathrm{C}$ for $5 \mathrm{~min}$ for M13. The amplification was conducted in duplicate for each sample to assess the reproducibility of the obtained patterns. The PCR products were determined by agarose gel electrophoresis, as previously described. The conversion, normalization and further analysis of the patterns were carried out with $\mathrm{FP}$ Quest ${ }^{\mathrm{TM}}$ software ver. 4.5 (Bio-Rad, USA).

\subsection{Antagonistic effect of the yeast strains}

The antagonistic effect of the yeast strains against Listeria monocytogenes ATCC 7644, Staphylococcus aureus ATCC 6538 and Enterococcus faecalis ATCC 29212 were evaluated by using agar spotting method.

The $3 \mu \mathrm{L}$ of $24 \mathrm{~h}$ cultures of the yeast isolates were spotted onto the surface of YEPD agar and incubated during 48-72 $\mathrm{h}$ at $30^{\circ} \mathrm{C}$. Then, the plates were covered by ten mililiter of $\mathrm{BHI}$ soft agar ( $0.7 \%$ agar) inoculated with $10 \mu \mathrm{L}$ of one of the Listeria monocytogenes ATCC 7644, Staphylococcus aureus ATCC 6538, and Enterococcus faecalis ATCC 29212 test cultures. After incubation during $18-24$ hours at $37^{\circ} \mathrm{C}$, the test plates were checked for clear inhibition zone diameters at around test cultures (Harris et al., 1989). The antagonistic effects of yeasts were also confirmed using neutralized supernatants (supernatant $\mathrm{pH}$ adjusted as 7.0) from the cultures.

\subsection{Proteolytic and lipolytic activity of the yeast strains}

Skim milk agar (Oxoid, UK) was used for determination of proteolytic activity of yeasts. Lipolytic activity was analyzed by spotting $24 \mathrm{~h}$ cultures of the yeasts on Tributyrin Agar (Oxoid, UK) and incubating at $30^{\circ} \mathrm{C}$ (Lanciotti et al. 2004).

\section{Results}

\subsection{Isolation and characterization of yeasts}

The yeast loads were between 1.47 and $4.71 \log$ cfu g $^{-1}$ in 24 of $50(48 \%)$ analyzed cheese samples in the study (Table 1). The yeast counts were of 2.87-4.71 log cfu g-1 for Tulum, 1.47-3.81 log cfu g-1 for Kashkaval, 3.61-4.36 log cfu g ${ }^{-1}$ for Mihalic, 2.68-4.71 log $\mathrm{cfu} \mathrm{g}^{-1}$ for Kelle, 3.44-4.17 log cfu g-1 for Orgu, $3.39 \log \mathrm{cfu} \mathrm{g}^{-1}$ 
for White, $2.91 \log _{\mathrm{cfu}} \mathrm{g}^{-1}$ for Sepet and $4.53 \log \mathrm{cfu} \mathrm{g}^{-1}$ for Goat cheese samples. (Table 1). Thirty-two yeast strains isolated from Turkish cheeses in the present study were ascribed to 11 different species by RFLP analysis and sequencing of ITS region. Table 2 shows the size of digested PCR products with HaeIII and HinfI

Table 1. The yeast counts and number of positive cheese samples.

\begin{tabular}{lcc}
\hline Cheese Type & $\begin{array}{c}\text { Yeast counts } \\
\left(\begin{array}{c}\text { minimum-maximum }) \\
\left(\log \mathrm{cfu} \mathrm{g}^{-1}\right)\end{array}\right.\end{array}$ & $\begin{array}{c}\text { Number of Positive } \\
\text { sample/Analyzed samples } \\
(\mathrm{n} / \mathrm{n})\end{array}$ \\
\hline Tulum & $2.87-4.71$ & $5 / 10$ \\
Kashkaval & $1.47-3.81$ & $6 / 14$ \\
Mihalic & $3.61-4.36$ & $4 / 6$ \\
Kelle & $2.68-4.71$ & $4 / 6$ \\
Orgu & $3.44-4.17$ & $2 / 5$ \\
White & 3.39 & $1 / 3$ \\
Sepet & 2.91 & $1 / 5$ \\
Goat & 4.53 & $1 / 1$ \\
\hline
\end{tabular}

and the results of ITS sequencing, performed on representatives of different RFLP profiles found. All the sequenced yeast isolates showed high similarity (100\% for all the isolates, except those of Rhodotorula mucilaginosa) to the sequences in Genbank (Table 2). The most frequent species was, as expected, Debaryomyces hansenii, with 16 isolates belonging to this species, followed by Torulaspora delbrueckii (3 isolates), whereas the species $K$. lactis, C. parapsilosis and Clavispora lusitaniae were present with two isolates for each one. Other species, such as S. cerevisiae, $K$. marxianus, Rhodotorula mucilaginosa, Meyerozyma guilliermondii (formerly Pichia guilliermondii), C. zeylanoides and C. albicans, were represented by only one isolate (Table 2).

\subsection{Molecular characterization using MSP-PCR}

Based on the identification results, yeast species including at least two isolates were submitted to molecular characterization at the strain level. The genetic polymorphism was analyzed using MSP-PCR with M13 and (GTG) ${ }_{5}$ primers.

Table 2. Molecular identification results of yeasts isolated from Turkish cheeses.

\begin{tabular}{|c|c|c|c|c|c|c|}
\hline \multicolumn{5}{|c|}{ ITS-5.8S RFLP (base pair) } & \multirow{2}{*}{$\begin{array}{c}\text { GenBank } \\
\text { Acc. Number }\end{array}$} & \multirow{2}{*}{ Species } \\
\hline Isolate & Source & $\mathrm{AP}^{\star}$ & HaeIII (bp) & Hinfl (bp) & & \\
\hline $39-1$ & Tulum cheese & 800 & No restriction & $390+410$ & - & T. delbrueckii \\
\hline $40-1$ & Tulum cheese & 850 & $320+230+180+150$ & $120+380$ & СР006446.1 & S. cerevisiae \\
\hline $40-2$ & Tulum cheese & 650 & $400+150+90$ & $325+325$ & - & D. hansenii \\
\hline 43-1 & Tulum cheese & 700 & $400+150+90$ & $325+325$ & - & D. hansenii \\
\hline $45-1$ & Tulum cheese & 690 & $400+150+90$ & $325+325$ & - & D. hansenii \\
\hline $47-1$ & Tulum cheese & 800 & No restriction & $390+410$ & - & T. delbrueckii \\
\hline $1-1$ & Kashkaval cheese & $750-800$ & $650+80$ & $90+120+200+260$ & KU311151.1 & K. marxianus \\
\hline $2-1$ & Kashkaval cheese & 690 & $400+150+90$ & $300+320$ & - & D. hansenii \\
\hline 4-1 & Kashkaval cheese & 600 & $450+120$ & $280+290$ & KP675554.1 & C. albicans \\
\hline 11-1 & Kashkaval cheese & 650 & No restriction & $90+120+230+220$ & AF444635.1 & Rhodotorula mucilaginosa \\
\hline 11-2 & Kashkaval cheese & 650 & $430+120+90$ & $300+320$ & KP053703.1 & Meyerozyma guilliermondii \\
\hline 21-1 & Kashkaval cheese & 550 & $110+400$ & $280+290$ & KC556814.1 & C. parapsilosis \\
\hline $49-1$ & Kashkaval cheese & 690 & $400+150+90$ & $325+325$ & - & D. hansenii \\
\hline $49-2$ & Kashkaval cheese & 690 & $400+150+90$ & $325+325$ & - & D. hansenii \\
\hline $12-1$ & Mihalic cheese & 700 & $400+150+90$ & $325+325$ & КР835570.1 & D. hansenii \\
\hline $12-2$ & Mihalic cheese & 700 & $400+150+90$ & $325+325$ & - & D. hansenii \\
\hline 13-1 & Mihalic cheese & 650 & $400+150+90$ & $325+325$ & - & D. hansenii \\
\hline $25-1$ & Mihalic cheese & 400 & No restriction & $200+200$ & - & Clavispora lusitaniae \\
\hline $25-2$ & Mihalic cheese & 690 & $400+150+90$ & $325+325$ & - & D. hansenii \\
\hline 33-1 & Mihalic cheese & 690 & $400+150+90$ & $325+325$ & - & D. hansenii \\
\hline 14-2 & Kelle cheese & 400 & No restriction & $200+200$ & - & Clavispora lusitaniae \\
\hline 19-1 & Kelle cheese & 690 & $400+150+90$ & $300+320$ & - & D. hansenii \\
\hline 28-1 & Kelle cheese & 550 & $110+400$ & $280+290$ & - & C. parapsilosis \\
\hline 29-1 & Kelle cheese & 690 & $400+150+90$ & $325+325$ & - & D. hansenii \\
\hline $14-2$ & Kelle cheese & 400 & No restriction & $200+200$ & - & Clavispora lusitaniae \\
\hline $30-1$ & Orgu cheese & 690 & $400+150+90$ & $325+325$ & - & D. hansenii \\
\hline $36-1$ & Orgu cheese & $750-800$ & $650+80$ & $100+120+200+300$ & KU218504.1 & K. lactis \\
\hline $36-2$ & Orgu cheese & $750-800$ & $650+80$ & $100+120+200+300$ & - & K. lactis \\
\hline $34-1$ & White cheese & 800 & No restriction & $390+410$ & KT029803.1 & T. delbrueckii \\
\hline $34-2$ & White cheese & 650 & $400+150+90$ & $325+325$ & KR089899.1 & Candida zeylanoides \\
\hline $31-1$ & Sepet cheese & 690 & $400+150+90$ & $325+325$ & - & D. hansenii \\
\hline $32-1$ & Goat cheese & 690 & $400+150+90$ & $325+325$ & - & D. hansenii \\
\hline
\end{tabular}

${ }^{*} \mathrm{AP}=$ size (base pairs) of the ITS-5.8S rDNA PCR product; RFLP = Restriksiyon Fragment Length Polymorphism. 
The numerical analysis (UPGMA clustering) of the combined MSP-PCR patterns with the two oligonucleotides resulted in the dendrogram reported in Figure 1. The reproducibility of the MSP-PCR was higher than $90 \%$ (data not shown). Clusters were arbitrarily identified at a similarity level of $60 \%$. The isolates were grouped in 6 main clusters and one single strain (56-2). The analyzed isolates were grouped according to the species, except $D$. hansenii isolates, which were separated into two clusters, 1 and 4. Cluster 1 was composed of one biotype, whereas cluster 4 could be further subdivided (at a similarity level of about $85 \%$ ) in three different subclusters, $4 \mathrm{a}, 4 \mathrm{~b}$, and $4 \mathrm{c}$, plus two single strains (49-1 and 19-1), indicating a significant polymorphism among $D$. hansenii strains. Certain biodiversity was also found in T. delbrueckii; in fact, one of the four strains grouped separately (56-2). The 56-1 and 56-2 strains were not cheese-derived. The others are included in cluster 5 , in which two biotypes can be individuated, the first one, shared by the isolates 34-1 and 39-1, and the other one, exhibited by 47-1. The two Cl. lusitaniae strains (cluster 3 ) showed different biotypes, as did the two K. lactis strains, composing cluster 6. Otherwise, the two C. parapsilosis isolates, belonging to cluster 2, showed the same biotype. MSP-PCR revealed a remarkably high genetic diversity within our set of strains; however, the low correlation with the source of isolation was found.

\subsection{Antagonistic effect of the yeast strains}

Only three of the yeast strains isolated from Kashkaval cheese samples (11-1, 49-1, 49-2) showed antagonistic effect (halos between 8.0-12.0 mm) against Listeria monocytogenes ATCC 7644. These strains were identified as Rhodotorula mucilaginosa (11-1) and D. hansenii (49-1, 49-2). The most effective antilisterial activity
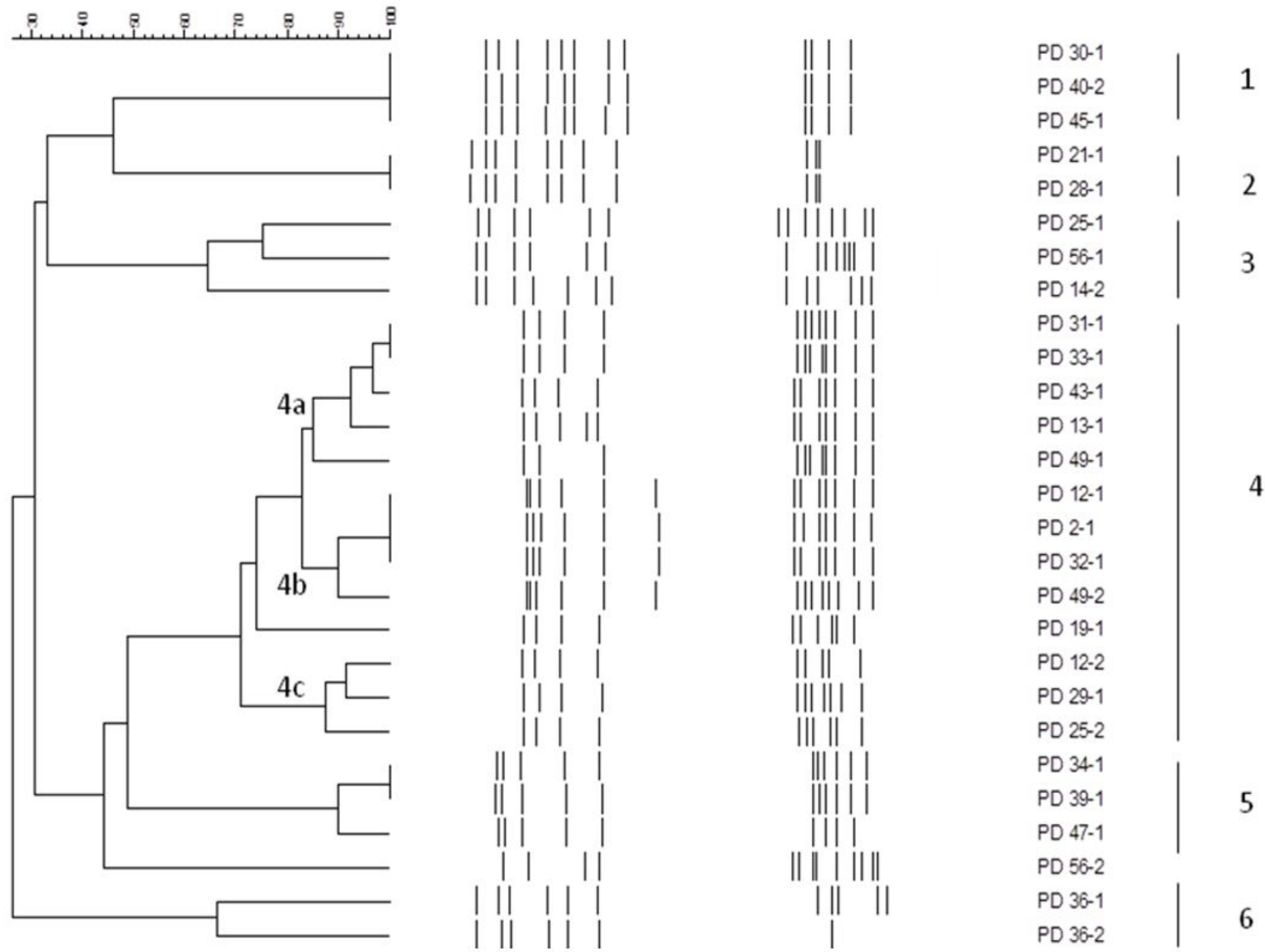

Figure 1. Cluster analysis of the profiles obtained by means of MSP-PCR with M13 and (GTG) oligonucleotides (PD 30-1; D. hansenii, PD 40-2; D. hansenii, PD 45-1; D. hansenii, PD 21-1; C. parapsilosis, PD 28-1; C. parapsilosis, PD 25-1; Clavispora lusitaniae, PD 56-1; Clavispora lusitaniae, PD 14-2; Clavispora lusitaniae, PD 31-1; D. hansenii, PD 33-1; D. hansenii, PD 43-1; D. hansenii, PD 13-1; D. hansenii, PD 49-1; D. hansenii, PD 12-1; D. hansenii, PD 2-1; D. hansenii, PD 32-1; D. hansenii, PD 49-2; D. hansenii, PD 19-1; D. hansenii, PD 12-2; D. hansenii, PD 29-1; D. hansenii, PD 25-2; D. hansenii, PD 34-1; T. delbrueckii, PD 39-1; T. delbrueckii, PD 47-1; T. delbrueckii, PD 56-2; T. delbrueckii, PD 36-1; K. lactis, PD 36-2; K. lactis). 
(12 mm) was determined in the Rhodotorula mucilaginosa (11-1) isolates (Table 1). The antagonistic effect against other tested pathogen bacteria was not shown.

\subsection{Proteolytic and lipolytic activities of the yeast strains}

Only the strain 36-1, identified as K. lactis and isolated from an Orgu cheese sample (Table 1), showed proteolytic activity. Lipolytic activity was not observed on tributyrin agar.

\section{Discussion}

Yeast counts are determined at a high level in cheeses (e.g., $10^{6}-10^{9} \mathrm{cfu} / \mathrm{g}$ ), even in cheeses produced by bacterial starters (Capece \& Romano, 2009; Karasu-Yalcin et al., 2017). In the present study, the yeast loads were found as too low (1.47-4.71 $\left.\log \mathrm{cfu} \mathrm{g}^{-1}\right)$ to affect in cheese ripening. The regulation limiting yeast and mold counts (1-2 log cfu g-1) (Turkish, 2010) and limited artisanal cheese production are thought to be the reasons of the low yeast counts in this study. The yeast count of Kashkaval cheese, a kind of pasta filata cheese, was determined in this study to range between 1.47 and $3.81 \log _{\text {cfu g}}{ }^{-1}$. Çetinkaya \& Soyutemiz (2006) reported the yeast and mold counts of Kashkaval cheese between 3.41 and $3.91 \log \mathrm{cfu} \mathrm{g}^{-1}$. There are some factors during the processing of Kashkaval cheese for reducing yeast count like heat treatment $\left(75 \pm 1^{\circ} \mathrm{C}\right.$ for $5 \mathrm{~min}$ ) of the curd during the stretching process (Çetinkaya \& Soyutemiz, 2006), and some chemical preservatives, which are allowed in limited amounts such as sorbates and benzoates, may also reduce yeast count (Ozdemir \& Demirci, 2006).

Yeasts are widely isolated from cheeses because of ability to live at acidic $\mathrm{pH}$, high salted environments, and storage at low temperatures of these foods. Yeasts may cause spoilage on dairy products contaminated through raw materials, additives, and other ingredients, and that may also occur due to environmental contamination, including surfaces of equipment (Fleet, 1990; Jakobsen \& Narvhus, 1996). However, some yeast strains have a desirable flavor and taste development during the ripening stage (Fleet, 1990).

In this study, the predominant isolated species from cheese samples was D. hansenii, especially in Tulum and Mihalic cheese. T. delbrueckii, K. lactis, C. parapsilosis, Cl. lusitaniae, S. cerevisiae, K. marxianus, R. mucilaginosa, Meyerozyma guilliermondii, C. zeylanoides, and C. albicans were found as other identified yeast species. It was mentioned that yeast species belonging to Debaryomyces, Candida, Kluyveromyces, Trichosporon, Saccharomyces, Pichia, Zygosaccharomyces and Geotrichum genera were the most generally isolated species from Turkish white pickled, Tulum and Kashkaval cheeses (Hayaloglu et al., 2002; Kavas et al., 2006; Karasu-Yalcin et al., 2012). Candida, Geotrichum, and Trichosporon genera were also identified as dominant yeast flora for Mihalic cheese (Karasu-Yalcin et al., 2017). It was mentioned that $D$. hansenii was the most widely found species in almost all cheeses types (Fleet, 1990; Capece \& Romano, 2009; Karasu-Yalcin et al., 2017). Debaryomyces hansenii has excellent tolerance to salty environments and proteolytic and lipolytic enzyme activty that are important for cheese ripening (Jakobsen \& Narvhus, 1996; Capece \& Romano, 2009).
Karasu-Yalcin et al. (2017) emphasized that it was expected to find $D$. hansenii as dominant yeast microflora of Mihalic cheese, a salty traditional cheese in Turkey.

Some yeast strains may show an antagonistic effect against pathogen bacteria by producing antibacterial compounds called mycocins (killer toxins). These compounds are glycoproteins or extracellular proteins which damage the cell membrane function in the targeted microorganisms (Hatoum et al., 2013). Although the antimicrobial effects of yeasts against other yeasts by killer toxins are well analyzed (Goerges et al., 2006; Buyuksirit \& Kuleasan, 2014), studies conducted to find out the antibacterial effects of yeasts against Listeria monocytogenes and Staphylococcus aureus are limited (Goerges et al., 2006; Roostita et al., 2011; Hatoum et al., 2013). Goerges et al. (2006) reported that C. intermedia, K. marxianus, and Pichia norvegensis yeast strains isolated from cheeses showed strong antilisterial activity. Roostita et al. (2011), reported that a C. parapsilosis isolate from yoghurt with fruits showed antibacterial activity against Pseudomonas aeruginosa, Escherichia coli and S. aureus. It has been reported that Candida catenulata, C. parapsilosis, C. tropicalis, D. hansenii, G. candidum, $P$. fermentans, and $P$. anomala strains obtained from raw milk and cheese products showed antilisterial activity against Listeria ivanovii. In this study, one $R$. mucilaginosa (11-1) and two D. hansenii (49-1, 49-2) strains exhibited antibacterial activity against $L$. monocytogenes. These three strains were isolated from Kashkaval cheese samples. Although a study about antilisterial activity potential of D. hansenii (Hatoum et al., 2013) has been published, to our knowledge, this research is the first report describing the antimicrobial activity of Rhodotorula mucilaginosa against Listeria monocytogenes. $R$. mucilaginosa has commonly been found in the microbial flora of some foods and beverages such as cherries, peanuts, fresh fruits, apple cider, fruit juice, sausages, cheese, crustaceans and edible mollusks, and has also been found in air, seawater, freshwater, and goat's milk (Wirth \& Goldani, 2012).

As a result of screening the proteolytic and lipolytic activity potential of the yeast isolates, proteolytic activity was only found in one K. lactis from Orgu cheese, and none of the isolates showed lipolytic activity in this study. Flores et al. (1999) also described proteolytic Kluyveromyces lactis strains.

\section{Conclusion}

Debaryomyces hansenii and Torulaspora delbrueckii were identified as predominant yeast species in traditional Turkish cheese samples. Although antilisterial and proteolytic activity potentials were determined in a limited number of strains, there is a need for more extensive studies to determine the technological properties of the yeast strains from natural yeast microflora of different traditional Turkish cheeses with a view to its possible use in the dairy industry.

\section{References}

Aday, S., \& Karagul Yuceer, Y. (2014). Physicochemical and sensory properties of Mihalic cheese. International Journal of Food Properties, 17(10), 2207-2227. http://dx.doi.org/10.1080/10942912.2013.790904. 
Altschul, S. F., Madden, T. L., Schäffer, A. A., Zhang, J., Zhang, Z., Miller, W., \& Lipman, D. J. (1997). Gapped BLAST and PSI-BLAST: a new generation of protein database search programs. Nucleic Acids Research, 25(17), 3389-3402. http://dx.doi.org/10.1093/ nar/25.17.3389. PMid:9254694.

Banjara, N., Suhr, M. J., \& Hallen-Adams, H. E. (2015). Diversity of yeast and mold species from a variety of cheese types. Current Microbiology, 70(6), 792-800. http://dx.doi.org/10.1007/s00284015-0790-1. PMid:25694357.

Büchl, N. R., \& Seiler, H. (2011). Yeast and molds: yeasts in milk and dairy products. In H. Roginski, J. W. Fuquay, P. F. Fox, eds. Encyclopedia of dairy sciences (2nd ed., pp. 744-753). New York: Elsevier. http:// dx.doi.org/10.1016/B978-0-12-374407-4.00498-2.

Buyuksirit, T., \& Kuleasan, H. (2014). Antimicrobial agents produced by yeasts. World Academy of Science, Engineering and Technology International Journal of Biological, Veterinary, Agricultural, and Food Engineering, 8, 999-1002.

Capece, A., \& Romano, P. (2009). "Pecorino di Filiano" cheese as a selective habitat for the yeast species, Debaryomyces hansenii, Short communication. International Journal of Food Microbiology, 132(23), 180-184. http://dx.doi.org/10.1016/j.ijfoodmicro.2009.04.007. PMid:19411124.

Capece, A., Pietrafesa, R., \& Romano, P. (2011). Experimental approach for target selection of wild wine yeasts from spontaneous fermentation of "Inzolia" grapes. World Journal of Microbiology \& Biotechnology, 27(12), 2775-2783. http://dx.doi.org/10.1007/s11274-011-0753-z.

Çetinkaya, F., \& Soyutemiz, G. E. (2006). Microbiological and chemical changes throughout the manufacture and ripening of Kashar: a traditional Turkish cheese. Turkish Journal of Veterinary and Animal Sciences, 30, 397-404.

Corbaci, C., Ucar, F. B., \& Yalcin, H. T. (2012). Isolation and characterization of yeasts associated with Turkish-style homemade dairy products and their potential as starter cultures. African Journal of Microbiological Research, 6, 534-542.

Esteve-Zarzoso, B., Belloch, C., Uruburu, F., \& Querol, A. (1999). Identification of yeasts by RFLP analysis of the 5.8S rRNA gene and the two ribosomal internal transcribed spacers. International Journal of Systematic Bacteriology, 49(Pt 1), 329-337. PMid:10028278.

Ferreira, A. D., \& Viljoen, B. C. (2003). Yeasts as adjunct starters in matured Cheddar cheese. International Journal of Food Microbiology, 86(1-2), 131-140. http://dx.doi.org/10.1016/S0168-1605(03)002526. PMid:12892928.

Fleet, G. H. (1990). Yeasts in dairy products. The Journal of Applied Bacteriology, 68(3), 199-211. http://dx.doi.org/10.1111/j.1365-2672.1990. tb02566.x. PMid:2187843.

Flores, M. F., Cuellas, A., \& Voget, C. E. (1999). The proteolytic system of the yeast Kluyveromyces lactis. Yeast, 15(14), 1437-1448. http:// dx.doi.org/10.1002/(SICI)1097-0061(199910)15:14<1437::AIDYEA445>3.0.CO;2-C. PMid:10514562.

Goerges, S., Aigner, U., Silakowski, B., \& Scherer, S. (2006). Inhibition of Listeria monocytogenes by food-borne yeasts. Applied and Environmental Microbiology, 72(1), 313-331. http://dx.doi.org/10.1128/ AEM.72.1.313-318.2006. PMid:16391059.

Hansen, T. K., \& Jakobsen, M. (2001). Taxonomical and technological characteristics of Saccharomyces spp. associated with blue-veined cheese. International Journal of Food Microbiology, 69(1-2), 59-68. http://dx.doi.org/10.1016/S0168-1605(01)00573-6. PMid:11589561.

Harris, L. J., Daeschel, M. A., Stiles, M. E., \& Klaenhammer, T. R. (1989). Antimicrobial activity of lactic acid bacteria against Listeria monocytogenes. Journal of Food Protection, 52(6), 384-387. http:// dx.doi.org/10.4315/0362-028X-52.6.384. PMid:31003307.

Hatoum, R., Labrie, S., \& Fliss, I. (2012). Antimicrobial and probiotic properties of yeasts: from fundamental to novel applications. Frontiers in Microbiology, 3 (421). http://dx.doi.org/10.3389/fmicb.2012.00421.

Hatoum, R., Labrie, S., \& Fliss, I. (2013). Identification and partial characterization of antilisterial compounds produced by dairy yeasts. Probiotics and Antimicrobial Proteins, 5(1), 8-17. http://dx.doi. org/10.1007/s12602-012-9109-8. PMid:26782600.

Hayaloglu, A. A., Guven, M., \& Fox, P. F. (2002). Microbiological, biochemical and technological properties of Turkish white cheese 'Beyaz Peynir' Review. International Dairy Journal, 12(8), 635-648. http://dx.doi.org/10.1016/S0958-6946(02)00055-9.

Jakobsen, M., \& Narvhus, J. (1996). Yeasts and their possible beneficial and negative effects on the quality of dairy products. International Dairy Journal, 6(8-9), 755-768. http://dx.doi.org/10.1016/09586946(95)00071-2.

Kamber, U. (2008). The traditional cheeses of Turkey: cheeses common to all regions. Food Reviews International, 24(1), 1-38. http://dx.doi. org/10.1080/87559120701761833.

Karasu-Yalcin, S., Senses-Ergul, S., \& Ozbas, Z. Y. (2012). Identification and enzymatic characterization of the yeasts isolated from Erzincan Tulum cheese. Mljekarstvo, 62, 53-61.

Karasu-Yalcin, S., Senses-Ergul, S., \& Ozbas, Z. Y. (2017). Enzymatic characterization of yeast strains originated from traditional Mihalic cheese. Journal of Microbiology, Biotechnology and Food Sciences, 6(5), 1152-1156. http://dx.doi.org/10.15414/jmbfs.2017.6.5.1152-1156.

Kavas, G., Kinik, O., Uysal, S., Kilic, S., Celikel, N., \& Akbulut, N. (2006). Characterisation of yeasts isolated from artisanal Turkish dairy products. International Journal of Dairy Science, 1, 44-50. http://dx.doi.org/10.3923/ijds.2006.44.50.

Lanciotti, R., Chaves-López, C., Patrignani, F., Paparella, A., Guerzoni, M. E., Serio, A., \& Suzzi, G. (2004). Effects of milk treatment with dynamic high pressure on microbial populations, and lipolytic and proteolytic profiles of Crescenza cheese. International Journal of Dairy Technology, 57(1), 19-25. http://dx.doi.org/10.1111/j.14710307.2004.00121.x.

National Center for Biotechnology Information - NCBI. (2015). Bethesda: NCBI. Retrieved from http://www.ncbi.nlm.nih.gov

Ozdemir, C., \& Demirci, M. (2006). Selected microbiological properties of Kashar cheese samples preserved with potassium sorbate. International Journal of Food Properties, 9(3), 515-521. http://dx.doi. org/10.1080/10942910600596191.

Roostita, L. B., Fleet, G. H., Wendry, S. P., Apon, Z. M., \& Gemilang, L. U. (2011). Determination of yeasts antimicrobial activity in milk and meat products. Advance Journal of Food Science and Technology, 3, 442-445.

Tarım ve Köyişleri Bakanlığı. (2010). Türk Gida Kodeksi Mikrobiyolojik Kriterler Tebliği (No. 27456). Resmî Gazete'de yayımlanarak yürürlüğe giren Türk Gıda Kodeksi. Retrieved from http://www.resmigazete. gov.tr/eskiler/2010/01/20100108-10.htm

Vasdinyei, R., \& Deak, T. (2003). Characterization of yeast isolates originating from Hungarian dairy products using traditional and molecular identification techniques. International Journal of Food Microbiology, 86(1-2), 123-130. http://dx.doi.org/10.1016/S01681605(03)00251-4. PMid:12892927.

Wirth, F., \& Goldani, L. Z. (2012). Epidemiology of Rhodotorula: an emerging pathogen. Interdisciplinary Perspectives on Infectious Diseases, 465717. https://doi.org/10.1155/2012/465717. 